\title{
Aspergillosis: from Allergic
Bronchopulmonary Aspergillosis to Invasive Aspergillosa
}

\section{Aspergillozis: Allerjik Bronkopulmoner Aspergillus'tan Invazif Aspergillozis'e}

Damla Serçe Unat' ${ }^{1}$ Aysu Ayrancı' ${ }^{1}$ Gülru Polat' ${ }^{1}$ Gülistan Karadeniz', Ömer Selim Unat², Fatma Demirci Üçsular?

\section{Abstract}

Allergic Bronchopulmonary Aspergillosis (ABPA) is a complex hypersensitivity reaction that develops in response to the colonization of the airways with Aspergillus fumigates. Aspergillus species are found in many places in nature, and while the inhalation of infectious conidia is a common occurrence, tissue invasion is rare, occurring most frequently in patients undergoing immunosuppressive therapy for hematological malignancy or solid organ transplantation. A 58-year-old male patient presented with dyspnea, cough and hemoptysis that had started 1 week earlier. The patient had been started on oral corticosteroid and itracanazole treatment following a diagnosis of ABPA 11 months previously. Computed tomography and laboratory findings were evaluated as invasive aspergillosis. Aspergillus fumigatus was identified in bronchial aspiration, and intravenous voriconasole was started. The patient's general condition worsened during follow-up and was transferred to intensive care, but died on the 3rd day of ICU hospitalization. Systemic corticosteroids applied for the treatment of many diseases should be used with caution due to their immunosuppressive properties, and the use of systemic corticosteroids in the treatment of ABPA must be carefully managed.

Key words: Allergic Bronchopulmonary Aspergillosis, Invasive Aspergilosis, Steroid.

\section{Özet}

Allerijk Bronkopulmoner Aspergillozis (ABPA), havayollarının Aspergillus fumigates ile kolonizasyonuna yanıt olarak gelişen kompleks bir hipersensitivite reaksiyonudur. Aspergillus türleri doğada pek çok yerde bulunur ve enfeksiyöz konidyumların inhalasyonu sık görülen bir olaydır. Ancak, doku invazyonu nadirdir. Doku invazyonu en sık olarak hematolojik malignite ya da solid organ transplantasyonu için immünsüpresif tedavi alan hastalarda görülür. Elli sekiz yaşında erkek hasta 1 hafta önce başlayan, dispne, öksürük ve hemoptizi şikâyeti ile başvurdu. On bir ay önce ABPA tanısı ile oral kortikosteroid ve itrakanazol tedavisi başlanan hastanın, bilgisayarlı tomografisi ve laboratuvar bulguları, invazif aspergillozis olarak değerlendirildi. Bronş aspirasyonunda aspergillus fumigatus üreyen hastaya intravenöz vorikanozol başlandı. Takiplerinde genel durumu kötüleşen hasta yoğun bakıma nakil verildi. Fakat yoğun bakım yatışının 3. gününde exitus oldu. Birçok hastalığın tedavisinde kullanılan sistemik kortikosteroidler, immünosupresif özellikleri nedeniyle dikkatli kullanılmalıdır. Bu nedenle, ABPA tedavisinde sistemik kortikosteroid kullanımı, dikkatle yönetilmesi gereken bir tedavi şeklidir.

Anahtar Sözcükler: Alleriik Bronkopulmoner Aspergillozis, Invazif Aspergillozis, Steroid.

\footnotetext{
'University of Health Science Dr. Suat Seren Chest Disease and Surgery Training and Research Hospital, İzmir, Turkey

${ }^{2}$ Departmant of Pulmonology, Ege University, İzmir, Turkey
} Dalı, İzmir

Submitted (Başvuru tarihi): 15.07.2020 Accepted (Kabul tarihi): 20.1 1.2020

Correspondence (iletişim): Damla Serçe Unat, University of Health Science Dr. Suat Seren Chest Disease and Surgery Training and Research Hospital, İzmir, Turkey

e-mail: sercedamla@gmail.com 
Allergic bronchopulmonary aspergillosis (ABPA) is a complex pulmonary disorder characterized by recurrent episodes of wheezing, fleeting pulmonary opacities and bronchiectasis. It is a hypersensitivity reaction that develops in response to the colonization of the airways with Aspergillus fumigates, and is usually seen in patients with asthma or cystic fibrosis $(1,2)$. The diseases referred to as "aspergillosis" includes those that take the form of allergies, airway or parenchymal disease, cutaneous infection or extrapulmonary spread with Aspergillus species (mostly A. fumigatus, A. flavus, and A. terreus). Aspergillus species are found in many places in nature, and the inhalation of infectious conidia is a common occurrence, while tissue invasion is rare, being most common in patients undergoing immunosuppressive therapy for hematological malignancy or solid organ transplantation (3).

Glucocorticoids have pleiotropic and suppressive effects on immune response, and play a therapeutic role in inflammatory, allergic, immunological and malignant diseases (4). Glucocorticoid toxicity is one of the most common iatrogenic disorders associated with chronic inflammatory diseases. The present study emphasizes the relationship between this case and the effect of glucocorticoids used in the treatment of ABPA, and the risk of invasive aspergillosis.

\section{CASE}

A 58-year-old male patient presented with complaints of dyspnea, cough, sputum, and half a tea glass of bloody sputum a day. His medical history indicated the use of inhaler corticosteroid + long-acting $\beta 2$ agonist treatment due to a diagnosis of asthma 9 years earlier. There was no smoking history, and no points of interest in his family history. His hemogram eosinophil level was measured as $2400 \mu \mathrm{L}$. The patient had high eosinophil levels in his blood and sputum, and his lgE level was 3256 (N: 0 165). An Aspergillus skin test was positive, and the patient was started on oral corticosteroid and itracanazole with a diagnosis of ABPA.

The patient developed dyspnea, cough, sputum and hemoptysis in the 11 th month of treatment, and a fever of $38.5^{\circ} \mathrm{C}$, respiratory rate $20 / \mathrm{min}$, blood pressure $100 / 75$ $\mathrm{mmHg}$ and pulse $110 / \mathrm{min}$. A respiratory examination revealed bilateral rales and expiratory rhonchi.

A posteroanterior (PA) chest $X$-ray revealed a bilateral diffuse reticulonodular density increase (Figure 1). The ABPA patient was hospitalized with a pre-diagnosis of pneumonia. The patient's blood leukocyte level was 21900/uL and CRP was $12.33 \mathrm{mg} / \mathrm{dL}$. The patient was started on piperacillin-tazobactam as a broad-spectrum antibiotic therapy.

Itracanazole treatment was continued, and on the 3rd day of hospitalization, leukopenia (2000/UI) developed and the patent's CRP level (31.4) increased. Oxygen therapy was started after the patient developed hypoxemia, and his oxygen level increased to $60 \mathrm{mmHg}$ from $50 \mathrm{mmHg}$ with $3 \mathrm{~L} / \mathrm{min}$ nasal oxygen therapy in his arterial blood gas. A PA chest $X$-ray showed a bilateral diffuse heterogeneous density increase (Figure 2), the galactomannan antigen was 1.82 (positive), and a Thoracic computed tomography (CT) revealed bilateral fibrocavitary lesions, increased diffuse homogeneous density, nodularity and ground-glass opacity, bronchiectasis areas and the "Halo" sign (Figure 3a and b)

The patient had hypotension $(79 / 50 \mathrm{mmHg}$ ) and tachycardia $(126 / \mathrm{min})$, and his arterial blood gas showed $\left(\mathrm{pO}_{2}: 54 \mathrm{mmHg}\right.$ ) hypoxemia. When the patient's lactate level reached 3.4, and thrombocytopenia $\left(64,000 / \mathrm{mm}^{3}\right)$, anemia and leukopenia (2000/uL) developed, he was transferred to the intensive care unit with a diagnosis of sepsis and invasive aspergillosis.

Aspergillus fumigatus was reproduced in the bronchial aspiration obtained during an intensive care fiberoptic bronchoscopy (FOB). No bacterial growth was observed in the sputum culture, but the blood galactomannan antigen level was noted to increase. The patient was consulted for infectious diseases, and intravenous voriconazole treatment was started. The patient's general condition worsened during follow-up and was subsequently intubated, but died on the third day of intensive care treatment due to sepsis secondary to invasive aspergillosis.

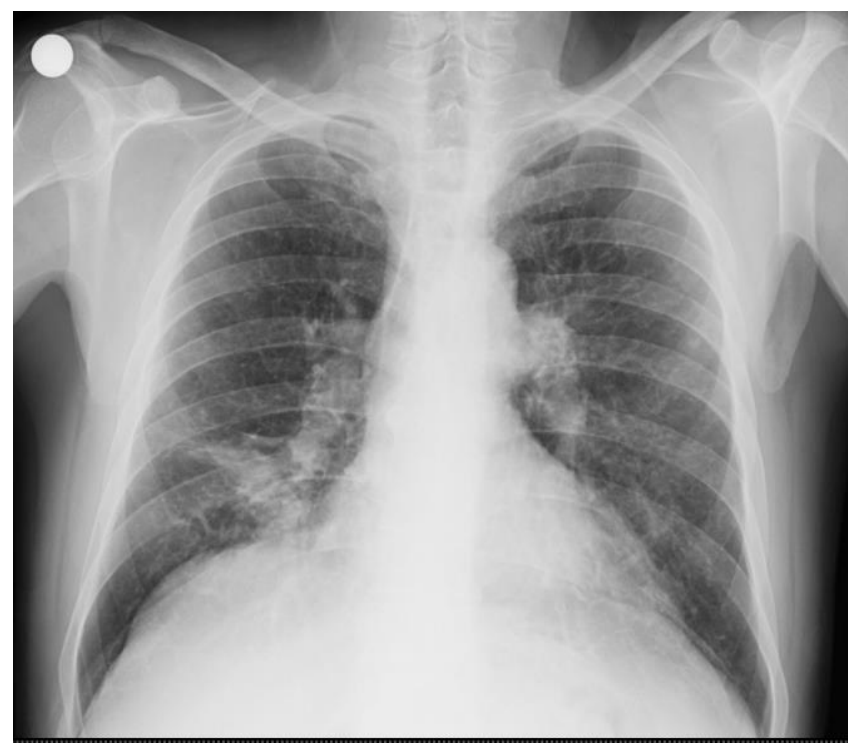

Figure 1: A PA chest $X$-ray revealed a bilateral diffuse reticulonodular density increase 


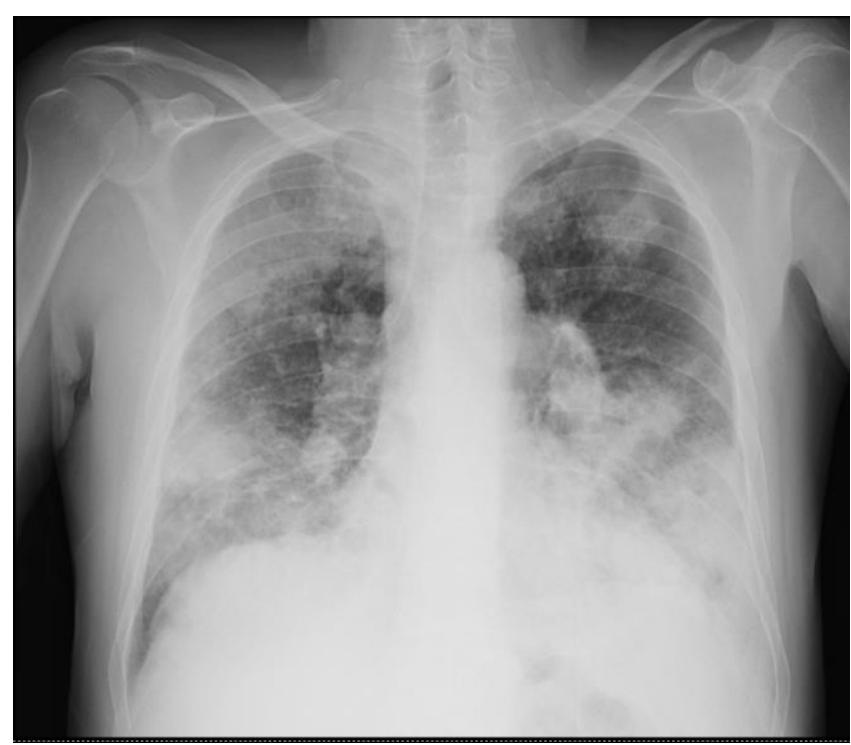

Figure 2: A PA chest X-ray showed a bilateral diffuse heterogeneous density increase
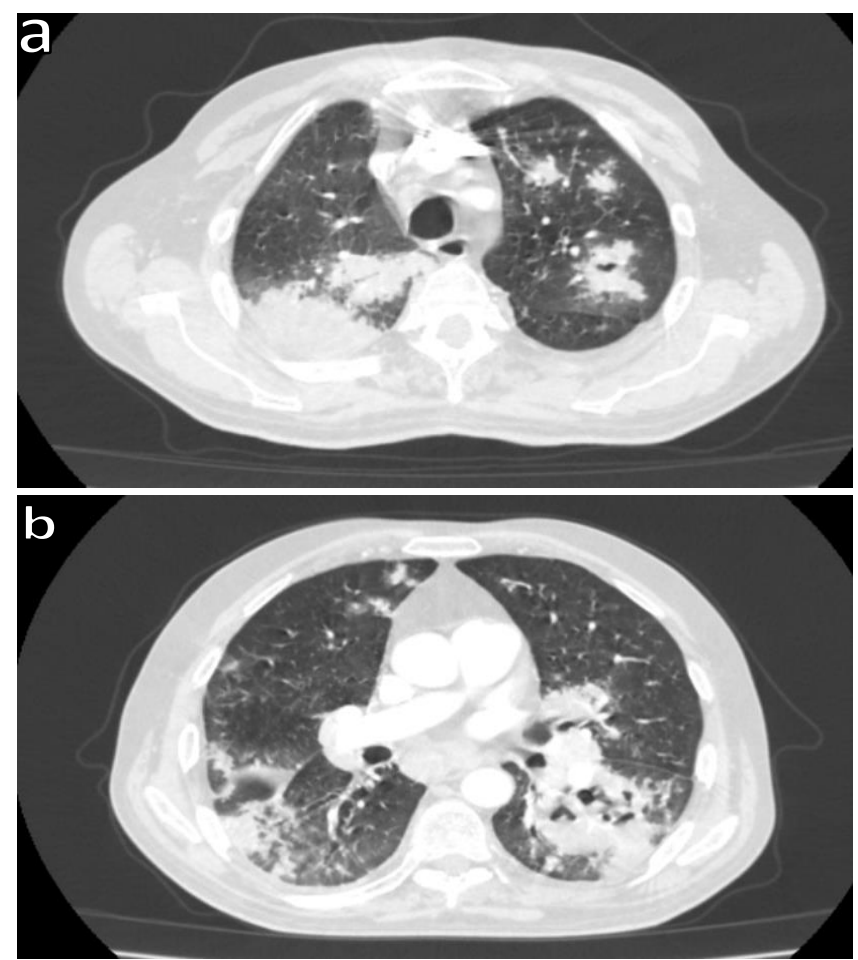

Figure 3a and b: A Thoracic CT revealed bilateral fibrocavitary lesions, increased diffuse homogeneous density, nodularity and ground-glass opacity, bronchiectasis areas and the "Halo" sign

\section{DISCUSSION}

Aspergillus species have emerged as an important cause of life-threatening infections in immunocompromised patients. The numbers of individuals who are immunocompromised is increasing day by day, and are primarily those with long-term neutropenia, advanced HIV infection, those with hereditary immune deficiency, and those who have undergone allogeneic hematopoietic stem cell transplantation (HSCT) and/or lung transplantation (5). Infections related to aspergillus species and aspergillus pneumonia are an important cause of mortality and morbidity in all immunosuppressed groups, especially in patients with HSCT (6-8).

The degree of infection of Aspergillus in the body varies depending on the immune response of the host (9). Allergic, saprophytic and invasive forms of aspergillus infections may be seen. Aspergillus hifa, when taken into the lungs via inhalation, may cause angioinvasion in the host as a result of failure of the immune response (10).

The most important criterion in diagnosis is the visualization of aspergillus reproduction in a culture analysis. While aspergillus reproduces easily in sputum cultures, its reproduction is rare in blood cultures. Bronchoalveolar lavage, transthoracic percutaneous needle aspiration or video-assisted thoracoscopic biopsy are standard procedures for the diagnosis of invasive pulmonary aspergillosis. The presence of septa with hives in direct microscopy in the samples obtained using these methods is sufficient for diagnosis $(2,5,11)$. Aspergillus hives were observed in bronchial aspiration obtained with $\mathrm{FOB}$ performed in the intensive care unit, however, other interventional procedures could not be performed due to the general condition of the patient.

Chest radiographs can reveal upper-lobe tubular branching opacities radiating out from the hilum in a bronchial distribution, classically referred to as the 'finger-in-glove' radiologic sign (12). CT plays an important role in the diagnosis of invasive pulmonary aspergillosis, with CT features to look out for being central or proximal upper lobe pre-dominant cystic or varicose bronchiectasis, treein-bud nodules, bronchial wall thickening and airtrapping (13). All of the radiological findings that may be seen in invasive aspergillosis were observed in the thorax CT of the presented case.

The Galactomannan antigen (GMA) test can also contribute significantly to the diagnosis of invasive aspergilosis, and can be studied from cerebrospinal fluid and bronchoalveolar lavage fluid. GMA is used not only for early diagnosis, but also for the evaluation of treatment response by serial follow-up. In the present case, the galactomannan antigen was found to be high, and was observed to have continued to increase at follow-up. Invasive aspergillosis can lead to mortality without adequate treatment, and sometimes even with adequate treatment. In the treatment of invasive aspergillosis, starting antifungal treatment early is the most important step (13-15). Oral or intravenous voriconazole has been the most commonly used antifungal medication applied for the treatment of invasive aspergillosis (16), although 
posaconazole, itraconazole, caspofungin and micafungin may also be used (5). In the present case, as soon as invasive aspergillosis was suspected, the patient was started on voriconazole. However, invasive aspergillosis is a lung infection that is associated with high mortality rates, and that may have a poor prognosis despite treatment. Our case died on the 3rd day of treatment.

The systemic corticosteroids used in the treatment of many diseases should be used with caution due to their immunosuppressive properties. Accordingly, the use of systemic corticosteroids in the treatment of ABPA must be carefully managed.

\section{CONFLICTS OF INTEREST}

None declared.

\section{AUTHOR CONTRIBUTIONS}

Concept - D.S.U., A.A., G.P., G.K., Ö.S.U., F.D.Ü.; Planning and Design - D.S.U., A.A., G.P., G.K., Ö.S.U., F.D.Ü.; Supervision - D.S.U., A.A., G.P., G.K., Ö.S.U., F.D.Ü.; Funding - D.S.U., G.P., G.K.; Materials - F.D.Ü., G.K.; Data Collection and/or Processing - D.S.U., A.A., Ö.S.U.; Analysis and/or Interpretation - Ö.S.U., A.A., G.P.; Literature Review - Ö.S.U., D.S.U., G.K.; Writing D.S.U., A.A., Ö.S.U.; Critical Review - F.D.Ü., G.P., G.K.

\section{YAZAR KATKILARI}

Fikir - D.S.U., A.A., G.P., G.K., Ö.S.U., F.D.Ü.; Tasarım ve Dizayn - D.S.U., A.A., G.P., G.K., Ö.S.U., F.D.Ü.; Denetleme - D.S.U., A.A., G.P., G.K., Ö.S.U., F.D.Ü.; Kaynaklar - D.S.U., G.P., G.K.; Malzemeler - F.D.Ü., G.K.; Veri Toplama ve/veya İşleme - D.S.U., A.A., Ö.S.U.; Analiz ve/veya Yorum - Ö.S.U., A.A., G.P.; Literatür Taraması - Ö.S.U., D.S.U., G.K.; Yazıyı Yazan - D.S.U., A.A., Ö.S.U.; Eleştirel İnceleme - F.D.Ü., G.P., G.K.

\section{REFERENCES}

1. Agarwal R, Sehgal IS, Dhooria S, Aggarwal AN. Developments in the diagnosis and treatment of allergic bronchopulmonary aspergillosis. Expert Rev Respir Med 2016; 10:1317-34. [CrossRef]

2. Patel AR, Patel AR, Singh S, Singh S, Khawaja I. Diagnosing allergic bronchopulmonary aspergillosis: a review. Cureus 2019; 27:11:e4550. [CrossRef]

3. Dixon WG, Abrahamowicz M, Beauchamp ME, Ray DW, Bernatsky S, Suissa S, et al. Immediate and delayed impact of oral glucocorticoid therapy on risk of serious infection in older patients with rheumatoid arthritis: a nes- ted case-control analysis. Ann Rheum Dis 2012; 71:1128-33. [CrossRef]

4. Cain DW, Cidlowski JA. Immune regulation by glucocorticoids. Nat Rev Immunol 2017;17:233-47. [CrossRef]

5. Walsh TJ, Anaissie EJ, Denning DW, Herbrecht R, Kontoyiannis DP, Marr KA, et al. Treatment of aspergillosis: clinical practice guidelines of the Infectious Diseases Society of America. Clin Infect Dis 2008; 46:327-60. [CrossRef]

6. El-Baba F, Gao Y, Soubani AO. Pulmonary aspergillosis: what the generalist needs to know. Am J Med 2020; 133:668-674. [CrossRef]

7. Takazono T, Sheppard DC. Aspergillus in chronic lung disease: modeling what goes on in the airways. Med Mycol 2017; 55:39-47. [CrossRef]

8. Azoulay E, Russell L, Van De Louw A, Metaxa V, Baver P, Povoa $P$, et al. Diagnosis of severe respiratory infections in immunocompromised patients. Intensive Care Med 2020; 46:298-314. [CrossRef]

9. Lam JM. Opportunistic fungal infection in children and management. Curr Opin Pediatr 2018; 30:514-9. [CrossRef]

10. Barnes PD, Marr KA. Aspergillosis: spectrum of disease, diagnosis, and treatment. Infect Dis Clin North Am 2006; 20:545-61. [CrossRef]

11. Rementeria A, Lopez-Molina N, Ludwig A, Vivanco AB, Bikandi J, Pontón J, et al. Genes and molecules involved in Aspergillus fumigatus virulence. Rev Iberoam Micol 2005; 22:1-23. [CrossRef]

12. Horvath JA, Dummer S. The use of respiratory-tract cultures in the diagnosis of invasive pulmonary aspergillosis. Am J Med 1996; 100:171-8. [CrossRef]

13. Stone S, Lynch D. Learning points for clinicians. Available from:

https://academic.oup.com/qimed/article/111/11/807/5 $\underline{033838}$ [CrossRef]

14. Becker MJ, Lugtenburg EJ, Cornelissen JJ, Van Der Schee C, Hoogsteden HC, De Marie S. Galactomannan detection in computerized tomography-based bronchoalveolar lavage fluid and serum in haematological patients at risk for invasive pulmonary aspergillosis. $\mathrm{Br} \mathrm{J}$ Haematol 2003; 121:448-57. [CrossRef]

15. Boutboul F, Alberti C, Leblanc T, et al. Invasive aspergillosis in allogeneic stem cell transplant recipients: Increasing antigenemia is associated with progressive disease. Clin Infect Dis 2002; 34:939-43. [CrossRef]

16. Semple T, Calder A, Owens CM, Padley S. Current and future approaches to large airways imaging in adults and children. Clin Radiol 2017; 72:356-74. [CrossRef] 